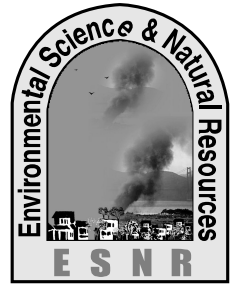

\title{
Microbiological Quality and Antibiogram of E. coli, Salmonella and Vibrio of Salad and Water from Restaurants of Chittagong
}

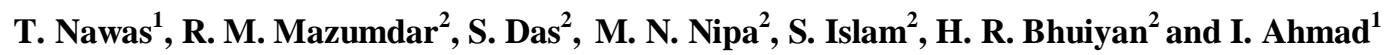 \\ ${ }^{1}$ Department of Food Engineering and Tea Technology \\ Shahjalal University of Science \& Technology, Sylhet \\ ${ }^{2}$ Industrial Microbiology Research Division, BCSIR laboratories Chittagong
}

\begin{abstract}
The study aimed at examining the microbial quality of restaurant salad and the water used for salad preparation and their role as a source of antibiotic resistant bacteria. Samples were collected from 15 different restaurants located in Chittagong city. The range of Total Viable Count was $1.86 \times 10^{4}$ to $7.28 \times 10^{5} \mathrm{CFU} / \mathrm{g}$ and $1.60 \times 10^{4} \mathrm{CFU} / \mathrm{ml}$ to $4.38 \times 10^{5} \mathrm{CFU} / \mathrm{ml}$ for salad and water respectively. Total colifrm and fecal coliform count $>1100 \mathrm{CFU} / 100 \mathrm{ml}$ were found in $73.33 \%$ of salad and $33.33 \%$ water samples. Salmonella spp was present in $46.67 \%$ of restaurants salad and water. Vibrio spp. was present in $66.67 \%$ of salad and $53.33 \%$ of water. A total of 102 isolates belonging to genus Vibrio, Salmonella and E. coli were subjected to antibiotic sensitivity test by disc diffusion method by using nine different types of antibiotic discs. Salmonella spp. from salad and water showed resistance against Amoxicillin (75\%), Cephradine and Cephalexin (68.75\%). 85.71\% Vibrio spp. isolated from salad and water were resistant to Amoxicillin respectively. Multiple drug resistance was seen in 39 and 51 isolates of Salmonella and Vibrio isolates, respectively. The results suggest the necessity to follow the hygienic practices in salad preparation and salad might have an important role as a source of multiple antibiotic resistant bacteria.
\end{abstract}

Key words: Antibiotic resistant bacteria, Microbiological quality, Salad, Water

\section{Introduction}

Salad is a dish of raw leafy green vegetables, often tossed with pieces of other raw or cooked vegetables, fruit, cheese, or other ingredients and served with a dressing. In Bangladesh salads are served with meals and snacks. However, food and water in particular have been described as vehicles for the transmission of microbial diseases, among which are those caused by coliforms (Ifediora et al., 2006). Some coliforms, including Salmonellae, Shigellae, and enteropathogenic Escherichia coli, are notable enteric pathogens. Escherichia coli O157:H7 and Salmonella spp. are the most dangerous food borne bacterial pathogens in terms of human health and disease (Olsen et al. 2000). The microbial load and the presence of the bacterial pathogens in foods are a good indication of the food quality and the potential health risk they pose to consumers (Rosmini et al. 2004). Various serotypes of Salmonella spp. have been reportedly responsible for food borne epidemics in various countries (Todd, 1997), emphasizing the importance of the pathogen as a food safety concern. In Europe, it has been reported that $25 \%$ of food borne outbreaks could be traced back to recontamination (WHO, 1995). Epidemiological evidence indicates that cholera is primarily a waterborne disease (Glass and Black, 1992). Besides drinking water, food has also been recognized to be an important vehicle of transmission of cholera. In developing countries, where both poverty and poor sanitation are common, faecal contamination of domestic and commercial food is likely to occur, and in many outbreaks the infection has been traced to consumption of faecally-contaminated foods (Rabbani and Greenough, 1999). In Dhaka, the capital city of Bangladesh, there were two outbreaks of cholera in 1974 and 1975 (Khan, 1983). The results of a case-control study indicated that the attack rates of cholera were significantly associated with eating in restaurants.

Fresh fruits and vegetables are perceived by customers to be healthy and nutritious foods owing to health benefits derived from consuming fresh products. Meldrum et al., (2009) reported that two large outbreaks in the United Kingdom demonstrated the significant health problems that could arise from consumption of contaminated salads. In all cases where antimicrobial treatment in humans is indicated, resistance to the antimicrobials of choice is of clinical importance. Resistant Salmonella involved in human disease are mostly spread through foods. With regards to Salmonella, contaminated poultry meat, eggs, pork and beef are prominent in this regard. Food is also an important source for human infections with antimicrobial resistant Vibrio spp. The presence of antibiotic resistant bacteria in water sources throughout the world has been documented (Kelch and Lee, 1978; French et al., 1987; Ogan and Nwiika, 1993). The majority of the studies focused on transferable drug resistance because of its practical importance (Pitout et al. 1998; Stapleton et al. 1999; Byarugaba, 2004).

The quality of drinking water in Bangladesh is also at high risk. Problems are acute, especially in the urban 
areas due to increased migration of rural people and increased economic growth as well. Chittagong, the commercial capital of Bangladesh, is one of the densely populated urban areas which has been suffering from inadequate supply of drinking water often associated with water quality problems too (UNCED, 1992). The principles that are applied to the prevention and control of the spread of pathogenic bacteria via food will also contribute to the prevention and the spread of antimicrobial-resistant pathogenic bacteria. As antimicrobial resistance in food borne pathogens and commensals represents a specific public health hazard, additional control measures for antimicrobial resistant bacteria may therefore be necessary (EFSA, 2008). In Bangladesh, a large number of people living in major cities and suburbs eat their meals in various roadside restaurants. In recent times, the microbiological safety of drinking water has become a burning issue and public awareness is gradually increasing regarding waterborne diseases.

This study was therefore carried out since there is currently no report on a comprehensive assessment of the bacterial health risk posed to consumers of salads across the Chittagong city.

\section{Material and Methods}

\section{Sample collection}

Salad ready to eat and water used in the kitchen were collected from the restaurants from different areas of Chittagong city, Bangladesh during March-April, 2011. 15 Samples from three types of restaurants R1, R2 and R3 (five from each) were collected. The salad samples and its corresponding water sample were coded as A, B, C, D, E, F, G, H, I, J, K, L, M, N, O and $\mathrm{W}_{1}, \mathrm{~W}_{2}, \mathrm{~W}_{3}, \mathrm{~W}_{4}, \mathrm{~W}_{5}, \mathrm{~W}_{6}, \mathrm{~W}_{7}, \mathrm{~W}_{8}, \mathrm{~W}_{9}, \mathrm{~W}_{10}, \mathrm{~W}_{11}$, $\mathrm{W}_{12}, \mathrm{~W}_{13}, \mathrm{~W}_{14}, \mathrm{~W}_{15}$ respectively.

Resturants were categorized into three different groups, R1(K,L,M,N,O), R2(A,B.F.G.J) and R3 (C,D,E,H,I) according to the cost, economic class of the customer and number of staff involved in serving. R1 restaurants were expensive; they had big space, many no. of staff $>10$ person to serve. Salads were not served free in these types and more than ten ingredients were used to prepare it. R2 types have fixed customers and number of stuff were not more than 5. They provided Salads with lunch for free. Restaurant of group R3 were small and number of stuff were less than 2 and salads were provided with lunch. R3 category restaurants were found beside the drain and road. Customers of these restaurants were mainly from the lower economy class. R2 and R3 category restaurants prepare the salad once or twice daily. Before serving they washed it with water. All the restaurants use water supplied by Chittagong Water Supply and Sewerage Authority (CWASA) for washing purpose. Customers of R2 and R3 types drink this water. But R1 restaurants provides water bottle.

\section{Sample processing}

All samples were collected in sterile polythene bag and plastic bottle in an insulated box and with ice to maintain a temperature ranging from $4^{\circ} \mathrm{C}$ to $6^{\circ} \mathrm{C}$ and analyzed within one hour after procurement. From each sample, $25 \mathrm{~g}$ was aseptically weighed and macerated and $225 \mathrm{ml}$ of sterile saline water $(0.9 \%)$ was added to the salad under laminar air flow to prepare stock solution. Sterile Serial dilution was carried out using sterile distilled water as diluents. Seven sterile test tubes were taken each containing 9 $\mathrm{ml}$ of sterile distilled water. Test tubes were labeled by $10^{-1}$ to $10^{-5}$. Before making any dilution, each of the water samples was shaken vigorously. $1 \mathrm{ml}$ of stock solution was added to a test-tube containing 9 $\mathrm{ml}$ of sterile water and thoroughly mixed to get a $10^{-1}$ dilution of the stock solution. $1 \mathrm{ml}$ of $10^{-1}$ dilution was transferred to $9 \mathrm{ml}$ of sterile water in another testtube and thoroughly mixed to get a $10^{-2}$ dilution. In such way serial dilution of stock solution were made up to $10^{-5}$.

\section{Bacterial enumeration and identification}

Isolation and enumeration of bacteria were done by growing them on selective and non-selective media such as nutrient agar for total viable count (TVC), Potato Dextrose Agar for yeast and mold count (YC), MacConkey broth for total Coliform (TC) and fecal Coliform (FC) count. The pathogen from the surface of samples were enriched in LB broth and isolated on selective media by streak plate method. Eosine methylene blue agar and Sorbitol Macconkey for pathogenic E. coli, Thiosulfate Citrate Bile Sucrose Agar (TCBS Agar) for Vibrios, Vibrio cholera like organism (VCLO), Xylose Lysine Deoxycholate Agar (XLD agar) and Salmonella-Shigella Agar (S-S Agar) for Salmonella, Tomato Juice Agar for Lactobacillus spp. Cetrimide Agar for Pseudomonas spp. and Mannitol salt phenol-red Agar was used for Staphylococcus spp. All the selective media were obtained from Himedia Laboratories Limited, Mumbai, India. Plates were made in triplicates in appropriate selective media. For bacterial and fungal enumeration spread plate was used to determine the number of colony forming units (CFU). For computation average number per plate is divided by sample volume and expressed as CFU/25g. Biochemical tests were of the enriched and isolated 
microbial isolates was done according to Bergey's manual of determinative Baceteriology (Holt, 1984).

\section{Antimicrobial susceptibility testing}

102 isolates of E.coli, Salmonella spp. and Vibrio spp. were tested for antibiotic resistance by the standard agar disc diffusion technique (Bauer et al 1966)) on Muller Hinton agar using commercial discs (Himedia, India). The following antibiotics with the disc strength in parentheses were Amoxicillin $(30 \mu \mathrm{g})$ , Chloramphenicol $(30 \mu \mathrm{g})$, Tetracycline $(30 \mu \mathrm{g})$, CoTrimoxazole $25 \mu \mathrm{g}$ ), Cephradine $30 \mu \mathrm{g}$ ), Ciprofloxacin $(30 \mu \mathrm{g})$, Cephalexin $(30 \mu \mathrm{g})$.

\section{Statistical Analysis}

SPSS software (V12) was used for statistical analysis and $T$ test was performed in the evaluation of the significance of the difference between the groups. The significance between the values was evaluated at $95 \%$ confidence $(\mathrm{p}<0.05)($ SPSS, 1999).

\section{Results and Discussion}

Range of microbial count of sald and water were $1.86 \times 10^{4}-7.28 \times 10^{5} \mathrm{CFU} / \mathrm{g}$ and $1.60 \times 10^{4}-4.38 \times 10^{5}$ $\mathrm{CFU} / \mathrm{ml}$ respectively. No difference was found in microbial load of salad and water in three groups of restaurants $(p>0.05)$. Total coliform and faecal coliform count were found more than 1100 in 11 (73.33\%) salad sample. The presence of faecal coliform in supply water indicate direct or indirect contamination from faecal origin. In the supply water sample Total coliform and faecal coliform count were estimated more than 1100 in five samples, W1, W2, W9 $9_{1}, \mathrm{~W} 10$, and W12 (Table 1). Total coliform and faecal coliform count were found nil in sample W3,W4, W6 and W11. $73.33 \%$ of salad and water were contaminated by coliform and fecal coliform. Salad and water from one restaurant were found free from coliform and fecal coliform. Colifrm and fecal coliform count were more than $1100 \mathrm{CFU} / 25 \mathrm{~g}$ were found in $73.33 \%$ (11) of salad samples. $33.33 \%$ (5) of water sample had count were more than 1100 $\mathrm{CFU} / 100 \mathrm{ml}$. The presence of Salmonella in $25 \mathrm{~g}$ of a sample examined is regarded as potentially hazardous to consumers, and is unacceptable for consumption (Cheung et al. 2007) and $13.33 \%$ salad sample were found unsatisfactory.

Table 1. Microbiological study of the salads and water collected from restaurants

\begin{tabular}{|c|c|c|c|c|c|c|c|}
\hline \multicolumn{2}{|c|}{ Salad } & \multicolumn{5}{|c|}{ Water } & \multirow[b]{2}{*}{$\begin{array}{c}\text { TVC } \\
(\text { CFU/m } \\
\text { L) }\end{array}$} \\
\hline ن & $\begin{array}{l}\text { Total } \\
\text { Coliform } \\
\text { (CFU/25gm) }\end{array}$ & $\begin{array}{l}\text { Faecal } \\
\text { coliform } \\
\text { (CFU/25g } \\
\text { m) }\end{array}$ & $\begin{array}{l}\text { TVC } \\
\text { (CFU/gm } \\
\text { ) }\end{array}$ & ن் & $\begin{array}{c}\text { Total } \\
\text { Coliform } \\
\text { (CFU/100 } \\
\text { ml) }\end{array}$ & $\begin{array}{c}\text { Faecal } \\
\text { coliform } \\
(\mathbf{C F U} / 10 \\
0 \mathrm{ml})\end{array}$ & \\
\hline A & $1100^{+}$ & $1100^{+}$ & $4.40 \times 10^{5}$ & W1 & $1100^{+}$ & $1100^{+}$ & $2.60 \times 10^{4}$ \\
\hline B & $1100^{+}$ & $1100^{+}$ & $1.20 \times 10^{5}$ & W2 & $1100^{+}$ & $1100^{+}$ & $3.24 \times 10^{5}$ \\
\hline $\mathrm{C}$ & $1100^{+}$ & $1100^{+}$ & $5.70 \times 10^{5}$ & W3 & 0 & 0 & $6.50 \times 10^{4}$ \\
\hline D & $1100^{+}$ & $1100^{+}$ & $1.20 \times 10^{5}$ & W4 & 0 & 0 & $4.70 \times 10^{4}$ \\
\hline $\mathrm{E}$ & $1100^{+}$ & $1100^{+}$ & $3.20 \times 10^{4}$ & W5 & 23 & 9 & $1.60 \times 10^{4}$ \\
\hline $\mathrm{F}$ & $1100^{+}$ & $1100^{+}$ & $2.80 \times 10^{5}$ & W6 & 0 & 0 & $5.80 \times 10^{4}$ \\
\hline G & 0 & 0 & $4.10 \times 10^{4}$ & W7 & 23 & 9 & $4.38 \times 10^{5}$ \\
\hline $\mathrm{H}$ & $1100^{+}$ & $1100^{+}$ & $1.86 \times 10^{4}$ & W8 & 9 & 9 & $1.89 \times 10^{5}$ \\
\hline I & $1100^{+}$ & $1100^{+}$ & $7.76 \times 10^{4}$ & W9 & $1100^{+}$ & $1100^{+}$ & $2.40 \times 10^{4}$ \\
\hline $\mathbf{J}$ & $1100^{+}$ & $1100^{+}$ & $5.31 \times 10^{4}$ & W10 & $1100^{+}$ & $1100^{+}$ & $2.10 \times 10^{5}$ \\
\hline K & 0 & 0 & $4.04 \times 10^{4}$ & W11 & 0 & 0 & $8.40 \times 10^{4}$ \\
\hline $\mathrm{L}$ & $1100^{+}$ & $1100^{+}$ & $7.28 \times 10^{5}$ & W12 & $1100^{+}$ & $1100^{+}$ & $7.60 \times 10^{4}$ \\
\hline M & 0 & 0 & $4.72 \times 10^{5}$ & W13 & 23 & 9 & $3.38 \times 10^{5}$ \\
\hline $\mathrm{N}$ & $1100^{+}$ & $1100^{+}$ & $2.48 \times 10^{5}$ & W14 & 23 & 9 & $3.40 \times 10^{5}$ \\
\hline $\mathrm{O}$ & 0 & 0 & $4.60 \times 10^{5}$ & W15 & 23 & 9 & $3.20 \times 10^{4}$ \\
\hline
\end{tabular}


Total 180 organisms (111from salad and 69 from water) were identified as Vibrio spp., Proteus spp., Enterobacter spp., Hafnia spp., Salmonella spp., E. coli, Serrtia spp., Citrobacter spp. and
Staphylococcous spp.. 102 isolates of three genera (Vibrio, Salmonella, E. coli) were then subjected to antibiotic sensitivity against nine frequently used antibiotics (Table 2).

Table 2. Occurrence of organisms in salad and water

\begin{tabular}{|c|c|c|c|c|c|}
\hline 을 & Ingredients & 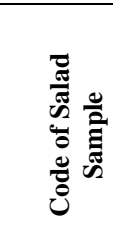 & 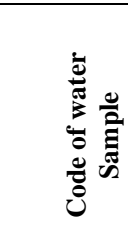 & $\begin{array}{r}\text { Identified } \\
\text { organisms } \\
\text { from salad }\end{array}$ & Identified organisms from water \\
\hline $\mathrm{R} 1$ & $\begin{array}{l}\text { Cucumber, Green pepper, } \\
\text { Tomato, } \\
\text { Yoghurt, } \quad \text { Coriander } \\
\text { Leaf, Sugar, Spice, Salt }\end{array}$ & $\begin{array}{l}\mathrm{K} \\
\mathrm{L} \\
\mathrm{M} \\
\mathrm{N} \\
\mathrm{O}\end{array}$ & $\begin{array}{l}\mathrm{W}_{11} \\
\mathrm{~W}_{12} \\
\mathrm{~W}_{13} \\
\mathrm{~W}_{14} \\
\mathrm{~W}_{15}\end{array}$ & $\begin{array}{l}\text { E. coli } \\
\text { Vibrio spp. } \\
\text { Salmonella spp. } \\
\text { Proteus spp. } \\
\text { Serratia } \text { spp. }\end{array}$ & $\begin{array}{l}\text { Enterobacter spp. } \\
\text { Proteus spp. } \\
\text { Vibrio spp. } \\
\text { Salmonella } \mathrm{spp} . \\
\text { Citrobacter spp. }\end{array}$ \\
\hline $\mathrm{R} 2$ & $\begin{array}{l}\text { Carrot, Cucumber, Green } \\
\text {, Papaya, Salt, pepper, } \\
\text { Onion, Pepper Mint }\end{array}$ & $\begin{array}{l}\text { A } \\
\text { B } \\
\text { F } \\
\text { G } \\
\text { J }\end{array}$ & $\begin{array}{l}\mathrm{W}_{1} \\
\mathrm{~W}_{2} \\
\mathrm{~W}_{6} \\
\mathrm{~W}_{7} \\
\mathrm{~W}_{10}\end{array}$ & $\begin{array}{l}\text { Salmonella spp. } \\
\text { Citrobacter spp. } \\
\text { Vibrio } \text { spp. } \\
\text { Serratia } \text { spp. } \\
\text { Proteus spp. } \\
\text { Hafnia spp. } \\
\text { Enterobacter spp. }\end{array}$ & $\begin{array}{l}\text { Vibrio spp. } \\
\text { Hafnia spp. } \\
\text { Vibrio spp. } \\
\text { Salmonella spp. } \\
\text { Staphylococcous spp. }\end{array}$ \\
\hline R3 & $\begin{array}{l}\text { Cucumber, } \\
\text { Green pepper, lemon, } \\
\text { Carrot, }\end{array}$ & $\begin{array}{l}\text { C } \\
\mathrm{D} \\
\mathrm{E} \\
\mathrm{H} \\
\mathrm{I}\end{array}$ & $\begin{array}{l}\mathrm{W}_{3} \\
\mathrm{~W}_{4} \\
\mathrm{~W}_{5} \\
\mathrm{~W} 8 \\
\mathrm{~W}_{9}\end{array}$ & $\begin{array}{l}\text { Proteus spp. } \\
\text { Enterobacter spp. } \\
\text { Salmonella } \text { spp. } \\
\text { Serratia } \text { spp. } \\
\text { Vibrio } \text { spp. }\end{array}$ & $\begin{array}{l}\text { Salmonella spp. } \\
\text { Citrobacter spp. } \\
\text { Vibrio spp. } \\
\text { Proteus spp. } \\
\text { Enterobacter spp. } \\
\text { Hafnia spp. }\end{array}$ \\
\hline
\end{tabular}

This result also indicated the possibility of fecal contamination and did not conform to the guideline of WHO(2001), which limits the number of fecal coliforms to be zero per $100 \mathrm{~mL}$ of water. Table 2 contains the data regarding specific bacteria detected in each of the samples. Biochemical tests revealed that all the samples were contaminated mainly with gram negative bacteria like E. coli, Shigella spp., Klebsiella spp., Enterobacter spp., Pseudomonas spp. and Salmonella spp., which are potential pathogens. Salad of 7 out of 15 restaurants were contaminated by Salmonella. E. coli were found only in two restaurant salad and Vibrio spp. was absent only in 5 salad sample. All the water used in restaurants are free from E. coli. A total of 34 isolates belonging to genus Vibrio, Salmonella and E. coli were subjected to antibiotic sensitivity test by disk diffusion method. Then zone of inhibition were interpreted according to NCCLS guideline and antibiotic sensitivity pattern were determined.

The antibiotic sensitivity pattern is summarized in the Table 4. The study was designed to determine the bacteriological quality of salads and water sold and consumed in restaurants of Chittagong city. All the salad samples examined were obtained ready for consumption from stewards in restaurants. The water samples collected, along with the salad samples, were those presented for drinking or used in washing utensils for serving the salads. The contaminated water samples could be the direct sources of ingestion of enteric pathogens or they could introduce pathogens to the salads through serving plates when they are used for washing. Coliforms in general and E. coli in particular are conventionally referred to as indicators of faecal contamination. When the vegetables cut as salads and storage for long time then those could have attributed to increase the microbial load. There are a number of reports indicating that raw vegetables may harbor potential foodborne pathogens (Nutt et al. 2003, Beuchat, 1996, Doyle, 1990, Nguyen-the \& Carlin, 1994) . Listeria monocytogenes, Salmonella (Doyle, 1990), and Escherichia coli (Nguyen-the \& Carlin 1994) have been isolated from raw vegetables. Okafo et al. (2003) reported the presence of Escherichia coli, Vibrio spp., and Salmonella spp. in raw vegetables harvested from soils irrigated with contaminated 
streams in Nigeria. Nipa et al., (2011) also reported the presence of Escherichia coli, Vibrio spp., and Salmonella spp. on raw salad vegetables in Chittagong city.

Contamination is the result of a combination of factors, including the unhygienic environment in which food is prepared and stored, and improper handling and preparation practices. Cooks generally prepare the salad with their bare hands, passing on germs to what they have on offer. The water used to prepare the foods and to clean the cooking and eating utensils - and sometimes even the swab cloths used for drying may be another source of contamination. The intensive use of food preparation areas provided many opportunities for crosscontamination between raw and prepared foods. Vendors make the salads contaminated during slicing, chopping and hand mixing. As per the Guideline of Hazard Analysis and Critical Control Points- Total Quality Management (HACCPTQM) (1998), the microbial quality on raw food. Raw foods containing $<10^{4} \mathrm{cfu} / \mathrm{g} / \mathrm{ml}$ of organisms is rated "Good" and those containing $>5 \times 10^{7} \mathrm{cfu} / \mathrm{g} / \mathrm{ml}$ as "Spoiled food". In Table -1 Total aerobic bacterial count of salads are in the range of $10^{4}-10^{5}$. According the HACCPTQM guideline, those samples can be considered as spoiled grade food and unsafe for consumer. HACCPTQM also indicate the threshold and quality stage for the illness hazards due to food borne microorganisms. For E.coli there is a level the estimated illness is $10^{6}$ $>10^{10} \mathrm{cfu}$. Occurrence of E. coli in samples indicates the possible potential of salads cause food borne illness.

$73.33 \%$ of the samples were contaminated with total and fecal coliform bacteria, which render those were unacceptable for human consumption. The samples were found to contain gram negative bacteria like $E$. coli, Shigella spp., Klebsiella spp., Enterobacter spp., Pseudomonas spp., and Salmonella spp., which are potential pathogens and thus pose a serious threat to public health (Moniruzzaman et al., 2011).Although coliform organisms may not always be directly related to the presence of fecal contamination, the presence of coliforms in water suggested the potential presence of pathogenic enteric microorganisms such as Salmonella sp., Shigella sp., and Vibrio cholerae (Zamberlan da Silva et al., 2008). According to WHO (Anonymous, 2006), the bacteria that pose a serious disease risk whenever present in drinking water include Salmonella sp., pathogenic E. coli and Vibrio cholerae. The presence of $E$. coli in water is nearly always associated with recent fecal pollution and it is the preferred indicator organism for his purpose (Eaton et al. 2005).
The high prevalence of coliforms in salads could be due to, amongst other factors, contaminated water used to clean equipment and cutting/slicing machines leading to cross-contamination especially if used with raw foods, handlers not practicing proper sanitation and faulty pasteurization equipment and monitoring devices. The isolation of coliforms from vegetables was not unexpected since water used to irrigate vegetable crops and the manure used as fertiliser are reported to contain coliforms and other enteric bacteria (Gagliardi and Karns 2000). The high prevalence and counts of coliforms found in the vegetables studied may, also be explained by the fact that the vegetable samples were not washed before processing. This was because the study was aimed at determining the risk associated with consuming these salads as purchased, bearing in mind that sanitary practices post-purchase and prior to consumption may vary across households in the country, in that a number of individuals consume these products as purchased.

CWASA of Bangladesh is supplying water to the Chittagong city dwellers through its distribution network after proper treatment of water drawn from the Halda River and groundwater source. But the quality of water is at risk to deteriorate during its flow through the distribution system as regular monitoring of the distribution network is not usually done. $74 \%$, $44 \%$ and $48 \%$ of isolates from salad were resistant to Amoxicillin, Cephradine and Cephalexin respectively (Fig. 1). Regarding isolates from water more than 80\% were resistant against Amoxicillin (Fig. 2).

None of them were resistant to Ciprofloxacin and Chloramphenicol. Salmonella spp. $66.67 \%$ from salad and $83.33 \%$ from water showed resistance against Cephradine and Cephalexin. All the isolates from salad and water were found sensitive to Ciprofloxacin and Chloramphenicol. Amirul Islam et al. (2010) found $65.62 \%$ isolates from fruits from markets of Chittagong city sensitive to Cholramphenicol. E.coli was found sensitive to all the tested antibiotics. $100 \%$ and $87.5 \%$ Vibrio spp isolated from salad and water were resistant to Amoxicillin respectively. More than $80 \%$ isolates from salad were sensitive to Chloramphenicol and Co-trimoxazole (Fig. 1). $91.17 \%$ isolates were multi drug resistant with a resistance to 2 to 5 antibiotics. $48.27 \%$ isolates were resistant to any three of the tested antibiotics (Fig. 3) and the maximum Amoxicillin, Cephradine, Cephalexin resistance pattern was observed in $37.93 \%$ isolates (21 salmonella spp. and 12 Vibrio spp. isolates) (Table 3). 
Antibiotic-resistant bacteria may readily penetrate into the gastrointestinal tract of a vegetable consumer (Österblad et al., 1999). Therefore, restaurants salad can be a potential source of bacteria resistant to antibiotics. Oluyege et al. (2009) reported $85 \%$ of the resistant isolates were multiple drug resistant where highest $(89.1 \%)$ resistance was to the amoxicillin. salad vegetables from different markets were highly contaminated by coliform and fecal coliform and Multiple drug resistance was observed in $98.06 \%$ isolates with a resistance to two to seven antibiotics (Nipa et. al. 2011). 96.07\% of isolates were found resistant to Ampicillin in the same study.

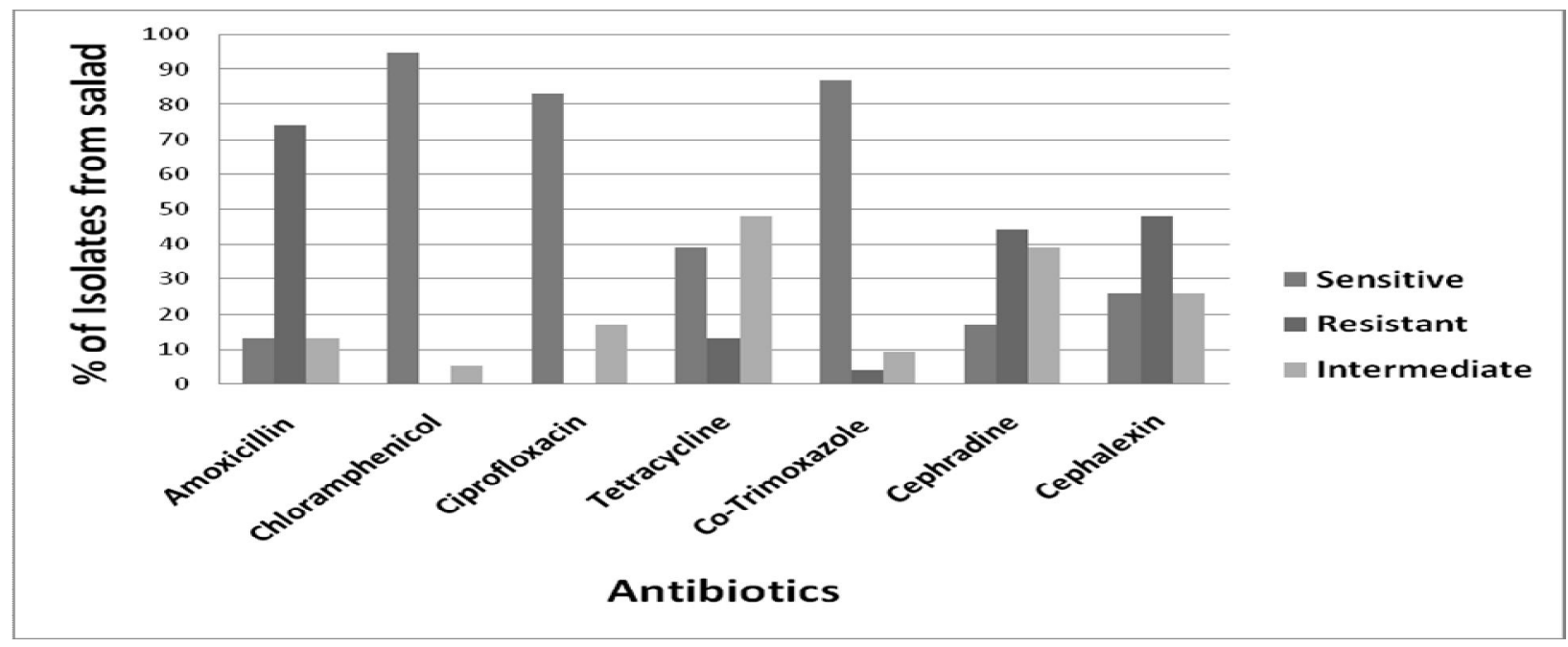

Fig. 1. Antibiotic sensitivity pattern of E. coli, Salmonella spp. and Vibrio spp. from salad

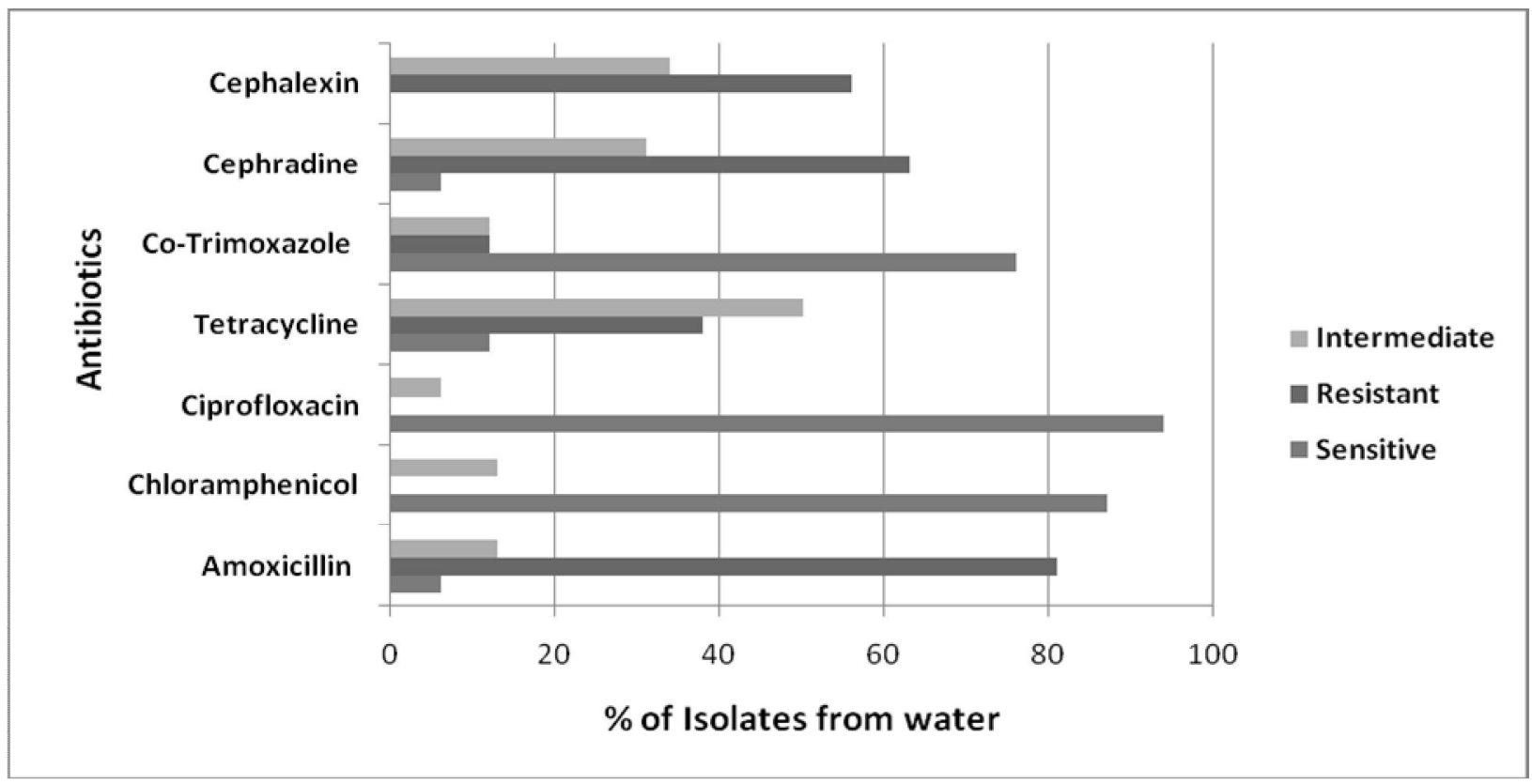

Fig. 2. Antibiotic sensitivity pattern of E. coli, Salmonella spp. and Vibrio spp. from water 


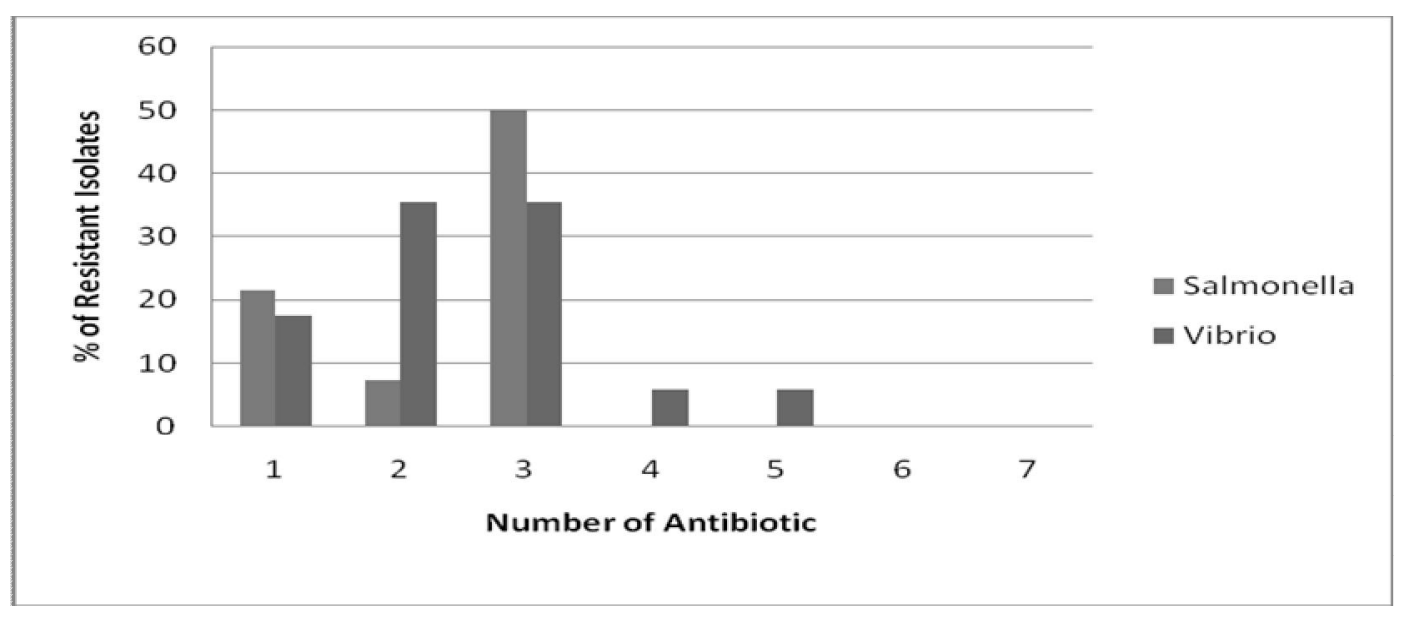

Fig. 3. Number of antibiotic resisted by Salmonella and Vibrio isolates

\section{Conclusions}

According to the results of this study vegetable salads may contain pathogenic bacteria; food pathogens can survive in vegetable salads, and thereby represent a risk to the consumers in regard to food borne disease and hygiene practice must be improved in all types of restaurants. Cholramphenicol and Ciprofloxacin are the most potent antibiotics to Samonella spp. and Vibrio spp.

\section{Acknowledgments}

We are greatful to Bangladesh Council of Scienific and Industrial Reasearch (BCSIR) and The Director of BCSIR Laboratories Chittagong, Bangladesh.

\section{References}

Anonymous. 2006. Guidelines for Drinking Water Quality. World Health Organization, Rome. Authority on foodborne antimicrobial resistance as a biological hazard. The EFSA Journal (2008), 765: 1-87.

Bauer, A.W., Kirby, M.D.K., Sherries, J.C. and Truck, M. 1966. Antibiotic susceptibility testing by a standardized single disk method. Am. J. Clin. Pathol., 45: 493-496.

Beuchat, L R. 1996. Pathogenic microorganisms associated with fresh produce. J. Food Prot., 59: 204-216.

Byarugaba, D. K. 2004. A view on antimicrobial resistance in developing countries and responsible risk factors. Int. J. Antimicrobial. Agents, 24: 105-110

Charles, W., Spyros, D. K. and Robert, B. Y. 1976. Enterobacteriaceae and P. aeruginosa recovered from vegetable salads. Appl. Environ. Microbiol., 31:453-454.

Cheung, P. Y., Kwok, K. K. and Kam, K. M. 2007. Application of BAX system, Tecra UniqueTM Salmonella test, and a conventional culture method for the detection of Salmonella in ready-to-eat and raw foods. J. Appl. Microbiol., 103: 219-227.

Doyle, M. P. 1990. Fruit and vegetable safetymicrobiological considerations. Hort. sci., 25: 1478-1481.

Eaton, A. D., Clesceri, L. S., Rice, E. W., Greenberg, A. E. and Franson, M. A. H. 2005. Standard Methods for the Examination of Water and Wastewater. 21st Edn., American Public Health Association, USA., ISBN-10: 0875530478.

EFSA. 2008. Foodborne antimicrobial resistance as a biological hazard. Draft Scientific Opinion of the Panel on Biological Hazards (Question No EFSA- Q-2007- 089). Draft endorsed on 6 March 2008.

French, G. L., Ling, J. Chow, K. W. and Mark, K. K. 1987. Occurence of multiple antibiotic resistance and R-plasmid in gram negative bacteria isolated from fecally contaminated freshwater streams. Epidemiol. Infect., 98: 285-299

Gagliardi, J. V. and Karns, J. S. 2000. Leaching of Escherichia coli O157: H7 in Diverse Soils under Various Agricultural Management Practices. Appl Environ Microbiol., 6(3) : 877883.

Glass, R. I. and Black, R. E. 1992. The epidemiology of cholera. In: Barua D, 
Greenough WB III, editors. Cholera. New York: Plenum, pp. 129-54.

Haccptqm Technical guidelines. Section IV contamination levels and Microbiological Control. 1998. http://www.hi-tm.com/Ifthzgui/Ift-IV.html.

Holt, J. G. 1984. Bergey's Manual of Systematic Bacteriology. Vol. I and II. Williams Wilkins, Baltimore, USA.

Ifediora, A.C., Nkere, C.K. and Iroegbu, C.U. 2006. Weaning food preparations consumed in Umuahia, Nigeria: evaluation of the bacteriological quality. $J$ Food Technol., 4: 101-105.

Islam, A., R.M. Mazumdar, Fakruddin, M. D. Islam, S. Nipa, M. N. Iqbal, A. Bhuiyan, H. R. 2010. Multiple Antibiotic Resistant Bacteria on Fruits from Different Markets of Chittagong City, Bangladesh. Bangladesh Res. Pub. J., 4(4): 342-350. http://www.bdresearchpublications.com/admin/journ al/upload/09184 /09184.pdf

Kelch, W.J. and Lee, J.S. 1978. Antibiotic resistance patterns of gram negative bacteria isolated from environmental sources. Appl. Environ. Microbiol., $36: 450-456$

Khan, M.U., Shahidullah, M., Ahmed, W.U., Purification D. and Khan, M.A. 1983.The eltor cholera epidemic in Dhaka in 1974 and 1975. Bull WHO, 61: 653-9.

Meldrum, R.J., Little, C.L., Sagoo, S., Mithani, V., McLauchlin J. and De Pinna, E. 2009. Assessment of the microbiological safety of salad vegetables and sauces from kebab take-away restaurants in the United Kingdom. Food Microbiol., 26: 573-577.

Moniruzzaman, M., Akter, S. Islam, M.A. and Mia, Z. 2011. Microbiological Quality of Drinking Water from Dispensers in Roadside Restaurants of Bangladesh. Pakistan Journal of Biological Sciences, 14: 142-145.

Nguyen-The, C. and Carlin, F. 1994. The microbiology of minimally processed fresh fruits and vegetables. Crit. Rev. Food Sci. Nutr., 34:370-401.

Nipa, M. N., Mazumdar, R.M. Hasan, M.D. M., Fakruddin, MD., Islam, S., Bhuiyan, H. R. and Iqbal, A. 2011. Prevalence of Multi Drug Resistant Bacteria on Raw Salad Vegetables Sold in Major Markets of Chittagong City, Bangladesh. MiddleEast Journal of Scientific Research, 10 (1): 70-77.

Nutt, J.D., X, Li., Woodward, CL., Zabala-Diaz, IB., Ricke, SC. 2003. Growth kinetics response of a Salmo-nella Typhimurium poultry marker strain to fresh produce extracts. Bioresource Technol., 89 : 313-316.

Ogan, M.T. and Nwiika, D.E. 1993. Studies on the ecology of aquatic bacteria on the Lower Niger delta: multiple antibiotic resistance among the standart plate count organisms. J. Appl. Bacteriol., 74 : 595-602
Okafo, C. N., Umoh, V. J. and Galadima, M. 2003. Occurrence of pathogens on vegetables harvested from soils irrigated with contaminated streams. Sci. Total Environ., 311: 49-56.

Olsen, S.J., Mackinnon, L.C. Goulding, J.S. Bean N.H. and Slutsker, L. 2000. Mmwr CDC Surveill. Summ. 49: 1 .

Oluyege, A. O., Dada, A. C., Ojo A. M. and Oluwadare, E. 2009. Antibiotic resistance profile of bacterial isolates from food sold on a University campus in south western Nigeria. African Journal of Biotechnology, 8 (21) : 883-5887

Österblad, M., Pensala, O., Peterzéns, Heleniusc M. and Houvinen, H. 1999. Antimicrobal susceptibility of Enterobacteriacea isolated from vegetables. $J$. Antimicrob. Chemother., 43: 503-509.

Pitout, J.D., Thomson, D., Hanson, K.S., Ehrhardt, N.D., Coundron, A.F. and Sanders, C.C. 1998. Plasmid mediated resistance to extendedspectrum Cephalosporins among Enterobacter aerogenes strains. Agents Chemother., 42: 596-600

Rabbani, G.H. and III Greenough, W.B. 1999. Food as a Vehicle of Transmission of Cholera. J Diarrhoeal Dis Res., 17(1):1-9.

Rosmini, M.R., Signorini, M.L., Schneider, R., and Bonazza, J.C. 2004. Evaluation of two alternative techniques for counting mesophilic aerobic bacteria in raw milk. Food Control, 15 (1) : 39-44.

SPSS, 1999. SPSS for Windows. SPSS Inc.,

Stapleton, P.D., Shannon, K.P. and French, G.L. 1999. Carbapenem resistance in Escherichia coli associated with plasmid-determined CMY-4 Blactamase production and loss of outer membrane protein. Antimicrob. Agent. Chemother., 43: 12061210 .

Todd, E. C., 1997. Epidemiology of foodborne diseases: a worldwide review. World Health Statistics Quarterly, 50 (1-2): 30-50.

UNCED. 1992. Protection of the Quality and Supply of Freshwater Resources: Application of Integrated Approaches to the Development, Management and Use of Water Resources. The United Nations Conference on Environment and Development. Chapter 18, Agenda 21.

WHO (World Health Organisation). 1995. Surveillance Programme. Sixth Report of WHO Surveillance Programme for Control of Foodborne Infections and Intoxications in Europe. FAO/WHO Collaborating Centre for Research and Training in Food Hygiene and Zoonoses, Berlin.

WHO (World Health Organization). 2001. Background paper: developing a food safety strategy. Geneva: World Health Organization. 16 p. (WHO strategic planning meeting). 